\title{
Resident Perceptions of Tourist Attractions on the Gold Coast of Australia
}

\section{Laura J. Lawton}

Laura J. Lawton is an assistant professor of Tourism and Event Management in the School of Hotel, Restaurant and Tourism Management at the University of South Carolina. She is also the Editor-in-Chief of Tourism Review International. The author gratefully acknowledges Australia's CRC for Sustainable for supporting this research with a competitive grant.

Address:

Dr. Laura J. Lawton, Assistant Professor

School of Hotel, Restaurant and Tourism Management

University of South Carolina

1000 Carolina Coliseum

Columbia, SC 29208

Telephone: (803)-777-7111

Fax: (803)-777-1224

E-mail: 1lawton@gwm.sc.edu

Keywords: resident perceptions; tourist attractions; personal construct theory; Gold Coast; Australia

Original Submission Date: July, 2004

Revised Submission: November 30, 2004

Published: November, 2005 


\section{Resident Perceptions of Tourist Attractions on the Gold Coast of Australia}

Personal construct theory was used to identify resident perceptions of 12 elicited tourist attractions on the Gold Coast of Australia. A cluster analysis of these residents revealed 'nature-biased' (45\%), 'unenthusiastic' (40\%), 'hinterland hesitant' (8\%), and 'enthusiastic' (7\%) groupings, with significant differences occurring in gender, length of residence and age. The finding that tourist attractions positively influence residents' quality of life despite the assessment of built attractions as commercialized, touristy, expensive and noisy/hectic may owe to the status of the Gold Coast as a tourism city. Tourism overall is perceived less positively than its constituent attractions, which may reflect the relatively less positive perceptions of one attraction in particular, Surfers Paradise. Revitalization of this iconic tourism district may therefore improve overall attitudes toward tourism among residents. 
Social impacts, as expressed through resident attitudes, have become an increasingly important focus of destination research. However, because they concentrate almost entirely on perceptions of tourism in general, such investigations fail to take into account the complexity of this sector. This shortcoming in the literature is addressed by examining residents' attitudes toward tourist attractions, which constitute the core component of tourism systems. The study will reveal variations in perception among an array of attractions, and also whether perceptions of the latter reflect or are distinct from attitudes toward tourism as a whole. A more in-depth profile and understanding of resident attitudes is the result, particularly since this study innovatively employs a framework based on Personal Construct Theory (PCT) to effectively elicit these attitudes. The Gold Coast of Australia was selected as the case study because of its domination by a mature mass tourism product that might be expected to yield negative community attitudes toward this sector, as per the classic destination life cycle model (Butler 1980).

The first section provides a brief review of the relevant literature relating to resident perceptions of tourism and tourist attractions. Subsequent sections describe the study area (including literature on Gold Coast resident perceptions studies), the underlying theoretical framework of Personal Construct Theory (PCT), and the research design. The results are then presented and their implications discussed.

\section{LITERATURE REVIEW}

The idea that the long-term viability of tourism depends on the maintenance of good relations with the local community has been recognized at least since the era of the 
"cautionary platform" in the 1970s (Jafari 2001). Classic deductive models of that period, including the Irridex (Doxey 1975), tourist/resident typology (Smith 1977) and the resort cycle (Butler 1980), suggest that intensified tourism development induces a resident backlash that could ultimately destabilize the destination. These models assume population homogeneity and a deterministic progression from more positive to less positive reactions to tourism. Subsequent empirical research, however, has found that resident reactions actually vary at any given time from unconditional enthusiasm to deep opposition, with ambivalent perceptions dominating (e.g., Davis, Allen, and Cosenza 1998, Ryan, and Montgomery 1994, Weaver and Lawton, 2001).

Faulkner and Tideswell (1997) encapsulate this complexity by suggesting that extrinsic factors such as development maturity and a high level of seasonality, which are often associated with resident disgruntlement, may be associated with positive assessments among residents displaying intrinsic characteristics such as employment in the tourism industry, frequent contact with tourists, and residence in a non-tourism zone. Resident reactions therefore are not tied entirely to a stage of development. Ap (1992) characterizes this dynamic as a manifestation of social exchange theory, wherein residents make tradeoffs between anticipated and actual costs and benefits (Jurowski and Gursoy 2004). For example, a resident who derives a good income from tourism may tolerate tourism-induced traffic congestion in return for the personal economic benefit (Pearce, Moscardo, and Ross 1996). Where these trade-offs occur at a collective level, an 'altruistic surplus' is evident that is, individual residents tolerate personal inconvenience if the community as a whole is seen to derive net benefits from tourism (Faulkner and Tideswell 1997). 
Intrinsic segmentation variables are emphasized in the literature, though with mixed results. The association between attitude and age is ambiguous, with older residents being found to be more positive toward tourism by Pigram (1987), Allen et al. (1988), King, Pizam, and Milman (1993) and Tomljenovic and Faulkner (2000), and less positive by Broughham and Butler (1981), Haralamopoulos and Pizam (1996), Lankford, Chen, \& Chen (1994), Ross (1991), and Son et al. (1999). Less ambiguous is length of residence, with long-time residents being found to have negative attitudes by Allen et al. 1988, Lankford et al. 1994, Perdue et al. 1995, Ross 1991, Schroeder 1992, Sheldon and Var 1984, Um and Crompton 1987, and Weaver and Lawton 2001. With regard to gender, Harvey, Hunt, and Harris (1995), Martin, McGuire, and Allen (1998), Milman and Pizam (1988), and Pizam and Pokela (1985) found females to be more negative, while Lankford, Williams and Knowles-Lankford (1994) and Son et al. (1999) found an opposite tendency. Several studies have revealed an association between high levels of education and support for tourism (Haralamopoulos and Pizam, 1996, Haukeland, 1984, Hernandez et al. 1996), although Husbands (1989) found that well educated Zambians were less enthusiastic. Haralamopoulos and Pizam 1996, Pizam 1978, and Schroeder 1992 found an association between positive attitudes and higher income, though this could be related to education, which is positively correlated with income. McMinn and Cater (1998), in contrast, found the highest levels of enthusiasm for tourism among low-income groups.

\section{Attractions and Residents}


The above studies consider the attitudes of residents toward tourism in general. There has been no concerted focus on tourist attractions in the literature, even though they are the core element of the tourism system and a primary influence on destination success (Gunn 1979, Mill and Morrison 1985, Lew 1987, McIntosh, Goeldner, and Ritchie 1995, Swarbrooke 1995, Weaver and Lawton 2002). Tourist attractions for the purposes of this study are defined as named events, sites, areas or linear phenomena with specific human or natural features that provide the focus of manager and visitor attention (modified from Pearce 1991). Tourism could not exist without the presence of attractions (Pigram 1983), which fundamentally influence the overall image and market profile of the destination (Mill and Morrison 1985), especially when these entail iconic attractions such as the Eiffel Tower or Great Wall of China. Tourists are drawn to destinations by their attractions, and it follows that the latter are major generators of revenue and employment for the host community.

Only a few studies have explicitly considered perceptions of residents toward tourist attractions. Alhemoud and Armstrong (1996) found that Kuwaiti university students were more impressed than English-speaking foreign residents with "manufactured" attractions such as resorts, while the foreigners were more favorably disposed toward cultural attractions. Neither group held positive images of Kuwait's natural attractions, though comparisons between the two groups are constrained by differences in English proficiency, length of residence, and familiarity with the country's attractions. Jurowski and Gursoy (2004) found that proximity to attractions influenced the way in which residents assessed tourism, with those living closer and using it more heavily being more negative about tourism, which they perceived as more of an imposition. Finally, several theme park studies 
contain a resident component (e.g. McClung 1991, Thach and Axinn 1994, Wong and Cheung 1999), in so far as local residents (i.e., those residing within $80 \mathrm{~km}$ ) constitute a portion of surveyed theme park users and non-users. However, this component is disguised by the fact that no explicit segmentation is made on the basis of local/non-local residence.

\section{THE STUDY AREA}

The Gold Coast is a city of 400,000 located just south of Brisbane (Queensland) and centrally within the Australian east coast pleasure periphery. It is the leading Australian example of tourism urbanization, which Mullin (1992) defines as “... the process whereby urban areas, particularly large cities, are specially developed for the production, sale, and consumption of goods and services providing pleasure" (p. 188). Tourism urbanization produces 'tourism cities' possessing distinct structural characteristics. One is the economic dominance of tourism. In the mid-1980s the Gold Coast accommodated about three million visitors per year. This increased to over seven million per year in the late 1990s (ATC 1985; BTR, 1986, 1999; Faulkner 1998), and to approximately 9.9 million in 2002/03 (GCCC 2004). Tourism accounts for a disproportionate share of the city's economy compared with other large Australian cities (ABS 1996).

A second characteristic is an image focused on hedonistic beach resort tourism, though recent attempts have been made to incorporate into this image the mountains and forests of its adjacent rural hinterland, in recognition of the purported 'greening' of the tourist market (Diamantis and Ladkin 1999; Poon 1993; Wight 1994). Spatial distinctiveness is a third primary characteristic. Gold Coast tourism focuses on a $40 \mathrm{~km}$ beach, adjacent to which 
resort accommodations, tourism shopping districts and built attractions such as theme parks have been established. The most intensive development occurs at Surfers Paradise, midway along the coastal strip, while theme park and golf course enclaves are scattered within the inland residential suburbs. Natural attractions such as Lamington and Springbrook National Parks are now considered integral to the Gold Coast tourism product, indicating a distinctive regional duality between built and nature-based attractions.

Rapid population growth is a fourth characteristic of tourism cities, with the 1961 Gold Coast population of 40,000 being less than one-tenth of the current population (ABS 19971998; ABS Gold Coast Office 1994; ABS Queensland Office 1974-1998). This growth, and a high level of transience (only one-third of residents in 1996 resided at the same address five years earlier, compared with one-half for Australia as a whole (Broome, Donkin, and O'Reilly 1999)), indicates a lack of stability that may affect perceptions of tourism and the development of a sense of community. Overall, the above characteristics combine with recent stagnation in visitation to indicate a late development or early stagnation stage of the destination life cycle, a juncture during which increasingly negative community attitudes toward tourism are expected (Butler 1980).

Gold Coast Resident Reactions to Tourism: Empirical Investigations

Several studies on the perceptions of Gold Coast residents toward tourism reveal diverse responses, but offer no evidence of a concerted backlash. Faulkner and Tideswell (1997), for example, found attitudes to be generally positive in terms of perceived economic benefits, but more negative with regard to congestion. Overall, residents strongly 
agreed, as per social exchange theory, that tourism positively affected their quality of life. Recent arrivals (10 years residence or less) were more positive toward tourism than longerterm residents, as were residents of inland suburbs. Weaver and Lawton (2001) identified similar patterns in the hinterland community of Tamborine Mountain, except that residential proximity to attractions was not a significant indicator of attitudes, and a substantial anti-tourism group was present that associated tourism with undesired urban sprawl from the Gold Coast. Tomljenovic and Faulkner (2000) found that older Gold Coast residents were more positive toward tourism than younger residents, possibly because many were retirees who migrated to the Coast for its ample recreational amenities.

In one of the few studies targeting resident perceptions of a specific attraction, Fredline and Faulkner (2000) found ambivalent attitudes toward the Indy, a major motor racing event. This is evident in the identification of 'hater', 'ambivalent supporter', 'realist', 'lover', and 'concerned for a reason' clusters. While almost all respondents (95\%) agreed that Indy promotes the Gold Coast as a tourist destination, strong majorities acknowledged the inconvenience caused by traffic congestion (79\%) and noise (75\%). Residents near the event site were more likely to express negative comments, but paradoxically also more likely to disagree with negative statements, perhaps indicating resignation or other personal adjustment to the event. An earlier study found that employees in tourism are more positive toward the Indy (Fredline 1997).

Overall, Gold Coast residents appear to be positive about tourism, though this is not unequivocal. They have demonstrated willingness in the past to resist perceived threats from tourism, as in an anti-Indy demonstration in the early 1990s that attracted over 1,000 residents concerned over anticipated environmental damage. More recently, local 
environmentalists vigorously opposed and defeated a proposed cableway that would have linked the coast with the rainforest-covered mountains of the hinterland.

\section{PERSONAL CONSTRUCT THEORY}

Personal construct theory (PCT) was used in this study to identify the perceptions of residents toward major tourist attractions on the Gold Coast. Originally conceived by Kelly (1995) as a technique in clinical psychology, this theory is based on the proposition that individuals generate and constantly reassess their own personal expectations about the nature of people and/or places in which they interact directly or vicariously. PCT, therefore, involves the personal schemata that individuals construct in order to make sense of and function within the world. In its original clinical applications, PCT focused on intraand inter-personal relationships and the roles played by participants within these relationships. To obtain relevant information, Kelly developed a repertory grid (RG) test that enabled patients to express and record their own worlds. The RG consists of elements and constructs, and a mechanism that links the two. Elements, in clinical psychology, are the stimuli relevant to each patient's particular situation (e.g., attractions). Constructs are 'the basic reference axes that form their (the respondents') dimensions of cognitive appraisal' (Potter 1986, p.85). In essence, they are ways in which an individual makes sense of or evaluate the elements. In PCT, constructs may be elicited through a variety of techniques, including the triadic method where subjects are presented with three elements (i.e. a triad) consisting of either people, places or objects, and asked to specify in what way two of these are alike, but different from the third (Fransella and Bannister 1977). Thus, 
elicited constructs are bipolar (hence Potter's "reference axes"). These consist of an emergent pole, or initial interpretation of an element given by the respondent (e.g., a patient's bother might be described as 'domineering'), and its implicit pole, or opposite characteristic that is obtained from the respondent through subsequent discussion (e.g., 'submissive').

Next, the respondent must score the elements against each of the identified constructs, usually through a five point Likert-type scale that allows for a useful range of evaluations without causing confusion or undo time delays in selecting values (Collett 1979). Scales of seven points, though used occasionally, are more difficult to examine visually, and exceed the limits of discrimination of most people (Stewart, Stewart, and Fonda 1981). Thus on the construct 'domineering-submissive', one element (e.g. the brother) might be rated as a ' 5 ' (for very domineering), while the sister might be assigned a ' 1 ', indicating 'very submissive'. The RG methodology minimizes the bias of the researcher by not forcing respondents to reply to a pre-determined scale, and allows respondents to provide their own elements and/or constructs (Timmermans, Van der Hijden, and Westerveld 1982). The most prevalent analytical technique used when dealing with large respondent numbers is the consensus grid or supergrid in which the mean responses of all respondents, as usually solicited in face-to-face interviews, are calculated for each cell in the RG (e.g., Pearce 1982; Potter and Coshall 1988; Young 1995). It has been the standard practice to subject the mean values of this consensus grid to principal component analysis (e.g., Walmsley and Jenkins 1993; Young 1995). However, these studies are constrained by the absence of any attempt to identify respondent sub-groups through rigorous statistical methods such as cluster analysis, which is the method used in the present study (see below). 


\section{PCT-Related Investigations of Perceptions}

PCT has evolved into a multi-dimensional and effective tool for gaining insights into a broad spectrum of situations within the social sciences. Geographers have used it to analyze consumer perceptions of urban retail shopping centers (Hudson 1974; Opacic and Potter 1986; Smith 1989; Timmermans, Van der Hijden, and Westerveld 1982), residential search behavior patterns (Preston and Taylor 1981; Aitken 1987); agricultural practices (Ibery and Hornby 1983, Townsend 1976), and to evaluate public perceptions about planning proposals (Fenton and Syme 1989; Stringer 1974). This interest results from the simplicity of the method and its adaptation to idiosyncratic environmental situations (Potter and Coshall 1988, p.64). The outdoor recreation and hospitality fields have also employed PCT, though in a more limited way. Alton and Leiber (1983) identified preference attributes as predictors for actual trail usage, while Sparrow and Wood (1994) identified the reaction of food servers to various customer-related situations. PCT has also been used to assess job performance dimensions among hotel managers (Anda Papadopoulou and Wilkie 1995).

PCT has been employed sporadically within the tourism literature to examine international tourist images of vacation destinations, including European seaside resorts (Riley and Palmer 1976) entire countries (Botterill and Crompton 1987, 1996; Embacher and Buttle 1989; Gyte 1988; Pearce 1982), domestic tourists' perceptions of Australian resorts (Walmsley and Jenkins 1993) and the selection of potential holiday destinations (Young 1995). It has also been used to identify tourist's images of major museums and art 
galleries in London (Coshall 2000). These studies all emphasise tourists who have visited, are visiting, or may visit the destination(s) in question. Far less common are PCT investigations into the perceptions of residents toward tourism or some aspect thereof. Potter and Coshall (1988) identified the tourism-related images that ten young Barbadians held of the country's counties, while Mansfeld and Ginosar (1994) revealed the views of residents in four Israeli towns toward tourism in those communities. Otherwise, PCT has been undeservedly neglected in tourism research according to Coshall (2000), and the research design outlined below is the first to use it to identify the perceptions of local residents toward local attractions.

\section{RESEARCH DESIGN}

A three-stage methodology was employed in this study, wherein (1) the elements were elicited, (2) the constructs were elicited, and then (3) the results of these initial stages were used to design and implement the RG.

\section{Stage 1: Eliciting Elements}

The first stage elicited the 'elements' or major Gold Coast tourist attractions from local residents. An elicitation approach was warranted by the scarcity of visitation and revenue data for specific attractions that would have informed the a priori selection of major attractions by the researcher. A random sample of 100 adult residents (15 years old or over) of the Gold Coast municipality, stratified by gender ( $48 \%$ male, $52 \%$ female), was 
contacted through the telephone directory. The distribution of these respondents by neighbourhood was compared to the Gold Coast population in general and found to be representative. The respondents provided an average of $3.84(\mathrm{SD}=2.40)$ attractions, with a range of 0 (three residents could not think of any attractions) to 12 (from one respondent). Between two and five responses were provided by $75 \%$ of the sample.

In determining the optimum number of tourist attractions for use in the RG, EasterbySmith (1981) suggest that the analysis is distorted by the use of less then six, while Smith and Leach (1972) propose 15 as ideal. The 12 most cited attractions were therefore selected. Major theme parks occupied three of the top four positions (Sea World [53\% of the sample], Movie World [47\%], Dreamworld [45\%]), with the 'beach' being cited by 47\%. The nature-based hinterland attractions of Tamborine Mountain (39\%), Springbrook National Park (27\%), O’Reilly's Rainforest Guesthouse (26\%), and Binna Burra Mountain Lodge (13\%) were the next most popular. The remaining attractions included an urban wildlife park (Currumbin [11\%]), another urban theme park (Wet 'n' Wild [10\%]), Lamington National Park (7\%) and Surfers Paradise (7\%).

\section{Stage 2: Elicitation of Constructs}

The second stage elicited the constructs used by residents to evaluate the 12 tourist attractions. A randomly generated triadic method was used (see above) using nine triads prepared in advance of the interview process to save time, to allow for the withdrawal of element cards with which respondents were not familiar, and to eliminate situations where a triad repeated at least two of the tourist attractions used in the previous triad. Such 
repetition may inhibit respondents from thinking of new constructs (Easterby-Smith 1981), and this was confirmed in a pilot study. Interviews were completed by telephone with 15 females and 15 males selected randomly from the Gold Coast directory. Additional interviews were unnecessary since no new constructs were elicited after the first 20 interviews. The average interview lasted 13.2 minutes. Twenty-eight respondents addressed all nine triads, while one each responded to six and five triads, indicating a high degree of familiarity with the elicited tourist attractions. Allowing for repeats, a total of 715 constructs were obtained (i.e., an average of 24 per respondent or 2.7 per triad), from which 124 different constructs were identified.

Categorizing and Distilling Constructs. It was necessary to categorize, distill and amalgamate the 124 constructs, since only a small number could ultimately be used in the stage 3 repertory grid analysis. First, Harrison and Sarre's (1975) classification scheme was used to distinguish between evaluative, relational and descriptive constructs (see Table 1), and only the 44 evaluative construct amalgams were retained, since these reveal the actual meanings that residents ascribe to particular tourist attractions (Young 1995). Similar constructs were then combined (e.g., 'expensive' with 'pricey'), and the combinations distilled by excluding those that were too vague (e.g., 'OK') or permeable (e.g., 'big'). Only one construct presented a potential problem. 'Not touristy-touristy' had been rejected in an earlier study by Walmsley and Jenkins (1993) as being too open-ended to be meaningful. However, the latter study involved a survey of tourists. From a resident perspective, this construct (which was not the result of any amalgamations) could be an indicator of local alienation toward particular attractions. It was therefore retained for 
further consideration. Finally, the remaining construct amalgams were ranked by frequency based on the original 715 citations. Only the top seven evaluative constructs were retained for Stage 3 (see Figure 1), because of a natural break between the $7^{\text {th }}$ and $8^{\text {th }}$ largest constructs, and also because this number facilitates the administration of the RG (see below).

'Insert TABLE 1 and FIGURE 1 here'

\section{Stage 3: Appraisal of Attractions by Residents: Employing the RG}

A questionnaire was posted to 2,000 Gold Coast residents in May 2001 to see how they judged the 12 attractions against the seven constructs. The sample was randomly and proportionately selected from the 2001 Queensland electoral roles using a random number table, after each electoral district was assigned a sample quota based on its share of the Gold Coast population. To increase the valid response rate and facilitate cluster analysis, potential residents were informed in the cover letter of the offer to have their name placed in a draw for AUS $\$ 500$ on the condition that they complete the entire questionnaire and return it within a stipulated period.

Questionnaire Design. The first section of the questionnaire presented the repertory grid exercises. A fundamental departure from previous RG studies was the use of 12 singleelement grids rather than a single grid combining all 12 tourist attractions and seven constructs. This allowed respondents to focus on each attraction separately, and avoided 
any need to explain the complexities of completing the element-by-attraction grid. It also allowed each construct-contrast pair on the RG to be qualified visually by the addition of 'very' or 'not at all' response options (i.e., 'very expensive' and 'not at all expensive') so that the correct interpretation of the cells at either extreme of the 5-point Likert scale would be clear to the respondents. The single-element grids also facilitated the addition of auxiliary questions following each element. For example, respondents were asked by way of a 5-point Likert scale question whether that particular attraction enhanced their quality of life. Subsequent sections of the questionnaire solicited the respondent's attitudes toward tourism development on the Gold Coast and respondent characteristics.

Analysis of Completed Repertory Grids. The completed repertory grids were analyzed in a two-stage process. The first involved a cluster analysis of respondents based on the 84 combinations produced by multiplying the seven constructs by the 12 tourist attractions. To prepare the data for cluster analysis, each of the 84 combinations was converted into a separate variable with its own column in a SPSS10.0 spreadsheet. The data from every respondent was then entered into rows. It is because cluster analysis can only be undertaken on questionnaires in which the respondent evaluated all 84 variables that the cover letter emphasized the need for respondents to fully complete the questionnaire. The second stage of the analysis involved a statistical comparison of the identified clusters against respondent characteristics and other relevant variables.

\section{RESULTS}


The initial and reminder letter mail outs produced 723 completed surveys, yielding a valid response rate of $38.1 \%$ after allowing for 104 unopened surveys returned because of incorrect addresses. Females accounted for $53.3 \%$ of the respondents, which corresponds to the female proportion of the adult Gold Coast population. Respondents on average had resided on the Gold Coast for 16 years, with the categories 'less than 10 years', ' 10 years or more but less than 20 years', and '20 years or more' each accounting for approximately one-third of the sample. Fredline (personal communication) also obtained a figure of 16 years in a study of Gold Coast adult resident attitudes toward the Indy. Most respondents reported high school, trade qualification or technical college as their highest level of educational attainment, and their geographical distribution by neighbourhood was representative. With regard to tourism, more than one-third of respondents $(36.8 \%)$ were working or had worked in the tourism industry and 55.8\% agreed or strongly agreed that 'The Gold Coast is a better place to live because of tourism'. This conforms to the positively skewed pattern of Gold Coast resident attitudes identified by Faulkner and Tideswell (1997).

\section{Overall Element Evaluations}

Table 2 depicts the overall mean responses obtained for all 84 element/construct combinations. Nature-based attractions (the beach, the National Parks, the ecolodges and Tamborine Mountain) were assessed as extremely natural, peaceful, affordable, interesting, not commercialized, not touristy and appealing. Theme parks and other urban attractions were generally regarded as interesting and appealing, but otherwise artificial, noisy/hectic, 
not affordable, commercialized and touristy. This was especially true for Surfers Paradise, with most respondents strongly agreeing that it is 'very touristy', 'very commercialised', 'very artificial' and 'very hectic/noisy'. However, just over one-half indicated that Surfers Paradise is 'appealing' or 'very appealing', and only 35.9\% assessed it as 'boring' or 'very boring'. The identification of patterns is assisted by Figure 2, which positions the attractions in a matrix where the $\mathrm{x}$-axis combines five constructs that align commonly and the y-axis combines two similarly aligned constructs. The attractions progress from a group of appealing nature-based sites (e.g. beach) to those which are artificial but still appealing (e.g. Dreamworld), and finally to artificial sites deemed less appealing (e.g. Surfers Paradise) (though not necessarily unappealing).

'Insert TABLE 2 \& FIGURE 2 here'

In terms of their impact on residents' quality of life, non-commercial nature-based attractions (Springbrook and Lamington National Parks, the beach and Tamborine Mountain) received the most positive scores, while commercial urban attractions (Dreamworld, Movie World, Wet 'n' Wild and Surfers Paradise) received the least positive rating (see Table 2). Three essentially nature-based but commercial attractions (Binna Burra, Currumbin, O’Reilly's and Sea World) occupied an intermediate position. Surfers Paradise had the only mean below 3.0 and produced the most diverse range of responses, yielding by far the greatest number of respondents who strongly disagreed (16.6\%) that it contributes positively to their quality of life. Almost all respondents had visited the beach (98.3\%) and Surfers Paradise (98.3), both recently and on numerous occasions. The 
remaining visitation rates in descending order were Sea World (97.1\%), Tamborine Mountain (95.9\%), Currumbin (90.3\%), Dreamworld (88.2\%), Springbrook National Park (80.1\%), Movie World (77.3\%), Lamington National Park (73.0\%), O’Reilly’s (69.8\%), Wet n’ Wild (64.7\%) and Binna Burra (62.9\%).

\section{Cluster Analysis Outcomes}

Cluster analysis, using Ward's method, was performed on the 84 element/construct variables depicted in Table 3, with two- to five-cluster solutions requested. Ultimately a four-cluster solution was accepted as providing the most effective differentiation of the sample. To assist interpretation, Table 3 provides mean responses from the four clusters to all seven constructs for five of the 12 tourist attractions, representing the continuum from urbanized/built (Surfers Paradise and Movie World) to urban/natural (Currumbin), naturebased/built (O’Reilly’s) and nature-based/natural (Lamington NP). Table 4, which depicts the cluster mean ratings on the quality of life effect of the tourist attractions, and Table 5, which compares the clusters against selected socio-demographic characteristics, also facilitate interpretation.

'Insert TABLE 3, 4 \& 5 here'

Cluster 1 - 'Nature-biased' $(n=331)$ 
Cluster 1 members account for almost one-half (45.8\%) of the sample and provide strongly positive assessments of the nature-based attractions in terms of impact on their quality of life, but lower than average (though still positive) assessments of built attractions (Table 4). Their assessments of the latter against the seven constructs are similar to the overall means depicted in the consensus grid (Table 2), but they are much more likely than the overall sample to regard nature-based attractions as highly natural, appealing, not at all commercialized, etc. This cluster, accordingly, is designated as 'nature-biased'. Average length of residence on the Gold Coast is the longest of any cluster (see Table 5).

Cluster 2 - 'Unenthusiastic' $(n=287)$

Members of Cluster 2, accounting for $39.7 \%$ of the sample, are characterised by lower than average quality-of-life ratings on the nature-based attractions and built attractions (Table 4). They tend to regard the latter as especially artificial, boring, unappealing, commercialized, etc. and do not see the nature-based attractions as being quite as natural, peaceful, etc. as the overall sample (Table 2). Given the equally lackluster assessments of both the nature-based and urban attractions, members of this cluster may be described as 'unenthusiastic'. There are no outstanding deviations from the overall sample on any variable except age, with members of this cluster being younger than members of other clusters (Table 5).

Cluster 3 - 'Hinterland Hesitant' $(n=58)$ 
Cluster 3 accounts for $8.0 \%$ of the sample and is notable for yielding the lowest quality-of-life means on nature-based attractions, and on the hinterland attractions of Springbrook NP, Lamington NP and O'Reilly's in particular (Table 3). This is corroborated by the finding that members are least likely to have visited the National Parks or ecolodge, while those who have visited have done so less frequently. The description of Cluster 3 as 'hinterland hesitant' is therefore appropriate, especially since members assign urban attractions more positive quality-of-life assessments. Cluster 3 displays the shortest length of residence and the highest proportion of low income earners, with $26.9 \%$ earning on average less than AUS\$16,000 per year, compared with $11.0 \%, 11.2 \%$ and $16.7 \%$ for members of Clusters 1, 2, and 4 respectively.

Cluster 4 - 'Enthusiastic' $(n=47)$

Cluster 4 (6.5\% of the sample) stands out for yielding the most positive quality-of-life assessments on both the nature-based and urban attractions and is therefore designated as 'enthusiastic'. For six attractions, these means are significantly higher than all other clusters (Table 4). While they may find urban attractions such as Surfers Paradise and Movie World to be artificial, commercialized, touristy, and expensive, they do not necessarily perceive them negatively since they still assess them as interesting and not boring (Table 3). Although no significant differences among the clusters were revealed on the statement of tourism's effect on making the Gold Coast a better place to live, Cluster 4 did produce the highest mean at 3.70 (vs. 3.33, 3.40 and 3.24 for Clusters 1, 2 and 3 
respectively). It was also distinguished by having an exceptionally high proportion of female members as well as the oldest membership (Table 5).

\section{DISCUSSION AND CONCLUSION}

This is the first study to examine residents' perceptions of a set of tourism attractions. Personal construct theory and the repertory grid $(\mathrm{RG})$ technique were employed to collect the relevant data, and cluster analysis was used to group the residents into relatively homogeneous categories. While the four-cluster solution was most amenable to interpretation, variability among the clusters is relatively subtle. For example, significant differences exist in how the clusters perceive Movie World on the construct 'commercialized-not commercialized', but all groups still regard it as more or less commercialized, and are generally positively inclined toward it and most of the other elicited attractions. No cluster can be unequivocally labeled as 'anti-attraction' or even negatively inclined in absolute terms toward either the nature-based or built attractions, which both appear to contribute to residents' quality of life and social sustainability. Prior applications of cluster analysis tended to reveal more clearly pro-, anti- and neutral or ambivalent groupings (e.g., Fredline and Faulkner 2000; Madrigal 1995; Martin 1995, Ryan and Montgomery 1994; Schroeder 1992; Weaver and Lawton 2001), though notably, these investigations, except for one on Indy (Fredline and Faulkner 2000), all focused on tourism in general. Speculation that this relatively subtle and positively skewed pattern of evaluation is peculiar to tourist attractions (excepting highly obtrusive events such as Indy, perhaps) is supported by the fact that Gold Coast residents are similar to residents solicited 
in the previous studies in being more divided about their assessment of tourism overall. One-quarter of residents disagreed or strongly disagreed that the Gold Coast is a better place to live because of tourism. However, subsequent analysis indicated that there were no significant differences among the clusters with respect to this statement. Attitudes toward the elicited group of attractions therefore appear at first glance to be independent from attitudes toward tourism overall.

It could be that even though local residents objectively identified these sites as tourist attractions, they also perceive and use them as recreational facilities and hence divorce them subconsciously from the broader and more abstract realm of 'tourism'. Another possibility is that the assessment of tourism is a reflection of attitudes toward one elicited attraction in particular, Surfers Paradise, which evoked the most negative responses. Unlike any other attraction, there was a significant positive correlation between the influence of Surfers Paradise on residents' quality of life and the perception that tourism makes the Gold Coast a better place to live $(r=.382, \mathrm{p} .<.000)$. Local business leaders recognise Surfers Paradise as an 'Achilles heel' and iconic 'hotspot' that generates negative perceptual repercussions for the entire Gold Coast region (Faulkner, 1998), and this has prompted a comprehensive 'Heart of the City' revitalization project for the district that among other objectives is attempting to attract more local recreational users (Stolz, 1999). Such an initiative could improve resident attitudes toward tourism in general, though the latter are not as negative as might be expected for a mature destination such as the Gold Coast. This, along with the positive assessment of attractions, might indicate a 'tourism city' variant of the destination life cycle in which many residents are attracted to city because of its tourism image and the presence of attractions that they utilize for their own 
recreational purposes. At the same time, the attitudes toward Surfers Paradise, which are more in line with the life cycle, indicates that even the residents of tourism cities have their tolerance limits.

Differential perceptions of built and natural attractions form the main basis for intercluster discrimination. This is evident in the large 'nature-biased' cluster and its opposite, the small group of 'hinterland hesitant' residents. The other two clusters are more uniform with respect to their evaluations, the main difference being the extent to which all attractions are positively perceived. Cluster 2 displays the least support overall, while the small Cluster 4 was clearly enthusiastic. Unfortunately, the absence of similar studies precludes comparison with other destinations. Significant differences between the clusters were found in quality of life assessments, visitation patterns, sex, age, length of residence and income. The 'hinterland hesitant' cluster best displays the visitation differential with less than one-half having ever visited Lamington and Springbrook National Parks or the two ecolodges. Moreover, those who have visited these sites have done so infrequently. The dominant reasons provided were lack of interest and lack of awareness. This may be related to the fact that the hinterland hesitants had resided on the Gold Coast for the shortest period of time and tend to have lower incomes.

It is unclear as to why females are over-represented in the small 'enthusiastic' cluster, especially as a comparison of male and female mean responses on the quality of life statements for all attractions revealed no significant differences. Moreover, Fredline (2001) identified no significant association between sex and cluster membership in a study of the Indy. The older age profile of the 'enthusiastic' cluster (53.8 years) contrasted with the relative youth of the 'unenthusiastic' cluster (46.6 years). Comparison of all older (50 
and older) and younger respondents against the quality of life statements showed that the former perceive the hinterland attractions more positively (except for Springbrook), while the latter regard Wet 'n' Wild, an amusement park, more positively. However, no significant differences are evident among any of the other urban-based attractions, and no significant difference in age exists between the two clusters ('nature biased' and 'hinterland hesitant') most differentiated on the basis of the natural/built distinction.

This study is methodologically innovative, with the telephone interviews, mail-out questionnaire, and single-grid-per-element approach effectively combining to obtain responses from residents. Unlike prior PCT research, this study elicited the elements, thereby obtaining valuable insights into residents' perceptions of major local tourist attractions. It also demonstrated the utility of eliciting both the elements and constructs by telephone rather than by face-to-face interviews. The questionnaire subsequently proved that it was possible to obtain a large number of valid evaluations without personal intervention and without having to reduce the number of tourist attractions and constructs employed in an exercise. The single-grid-per-element approach in the RG exercise was instrumental in this regard. Finally, cluster analysis was successfully used to group residents with similar response patterns (rather than just elements or constructs as in earlier studies) by converting the cumulative 84 element/construct combinations in the RG to separate variables amenable to multivariate analysis. In sum, the methodology provides a useful template for any tourism research involving respondent assessments of multiple tourist attractions.

\section{Limitations and Further Research}


Perhaps more citations to the Indy would have been obtained if the element elicitation exercise had occurred closer to or during this event. High profile shopping malls (e.g., Pacific Fair) and the casino were also insufficiently cited, perhaps because the latter's identity as an attraction is obscured by its dominant visual identity as just another large hotel, while the frequent use of Pacific Fair by residents may have a similar obscuring effect. Knowing that these were important tourist attractions, it may have been prudent to incorporate them into the study on the basis of researcher discretion as supplied elements. The utility of telephone directories for generating the elicitation samples is constrained by the exclusion of residents who do not possess a telephone, have an unlisted number, are new arrivals, or are reluctant to answer the telephone. Non-response bias may be present given the response rate to the questionnaire, and it appears that younger males are underrepresented in the sample. Some respondents may have completed all of the RG exercises without having actually heard of one or more attractions in order to qualify for the incentive prize, or out of a sense of obligation because the instructions emphasized the need to complete the entire survey. Finally, while the study clearly revealed personal benefits derived from respondents' recreational use of attractions as well as recognition of costs such as congestion, the questionnaire was not structured so as to explicitly identify any pattern of trade-offs that would corroborate or refute the dynamics of social exchange theory. This should be included in follow-up research that investigates the extent to which these patterns are ubiquitous, idiosyncratic to the Gold Coast, or characteristic of tourism cities in general. 
Additional research is also needed to see why attractions such as the beach, Tamborine Mountain and Surfers Paradise are perceived generically even though they are comprised of distinct sub-attractions (e.g., there are about 30 named beaches on the Gold Coast). Other topics include the clarification of residents' interaction with attractions such as Surfers Paradise that also function as transit area, workplace and residence. It would also be useful to more closely examine the relationship between proximity to an attraction and resident attitudes. This was not feasible in the present study due to the nature of the sample, which produced no more than a few individuals residing near any given attraction. Future research could employ cluster sampling to redress this outcome, thereby allowing statistical analysis to be undertaken based on proximity. This would also allow social management strategies, such as the practice of some theme parks to provide nearby residents with privileges such as free entry passes, to be assessed. 


\section{REFERENCES}

ABS (Australian Bureau of Statistics). (1997-1998). Year Book of Australia, 1975-76 1998. Canberra, ACT: Commonwealth of Australia. . (1996). Cdata96 (1996 Australian Census data)(CDROM package). Canberra, Australia: BTR.

ABS (Australian Bureau of Statistics). Gold Coast Office. (1994). Gold Coast Region: A Social Atlas. Brisbane, QLD: ABD

ABS (Australian Bureau of Statistics). Queensland Office. (1974-1998). Queensland Year Book, 1974-1986. Brisbane, QLD: Government Print.

Aiken, S. C. (1987). "Households Moving within the Rental Sector: Mental Schemata and Search Spaces.” Environmental and Planning A, 19: 369-383.

Alhemoud, A. M., and E. G. Armstrong (1996). "Image of Tourism Attractions in Kuwait." Journal of Travel Research, 34(4), 76-80.

Allen, L. R., P. T. Long, R. R. Perdue, and S. Kieselbach (1988). “The Impact of Tourism Development on Residents' Perceptions of Community Life.” Journal of Travel Research, 27(1): 16-21.

Alton, L. R., and S. R. Leiber (1983). “Attributes of Chicago Trail Areas.” Leisure Sciences, 5(3): 197-220.

Anda Papadopoulou, E. A., and D. T. Wilkie (1995). “Convergence between Sources of Service Job Analysis Data.” International Journal of Contemporary Hospitality Management, 7(2/3): 42-47. 
Ap, J. (1992). "Residents' perceptions on tourism impacts.” Annals of Tourism Research, 19(4): 665-690.

ATC (Australian Tourist Commission). (1985). International Visitor Survey, 1985 Summary. Melbourne, Australia: ATC.

Botterill, T. D., and J. L. Crompton (1987). "Personal Constructions of Holiday Snapshots." Annals of Tourism Research, 14(1): 152-156.

Botterill, T. D., and J. L. Crompton (1996). "Two Case Studies Exploring the Nature of the Tourist's Experience." Journal of Leisure Research, 28(1): 57-82.

Broome, G., J. Donkin, and I. O’Reilly (1999). Our Community: A Social Profile of the City of the Gold Coast. Gold Coast, Australia: The Social Research Section, Gold Coast City Council.

Brougham, J.E., and R. W. Butler (1984). “A Segmentation Analysis of Resident Attitudes to the Social Impact of Tourism.” Annals of Tourism Research, 8(4): 569-590.

BTR (Bureau of Tourism Research). (1986). International Visitor Survey, 1986. Canberra, Australia: BTR.

. (1999). International Visitors in Australia, 1998: Annual Results of the International Visitor Survey. Canberra, Australia: BTR.

Butler, R. W. (1980). “The Concept of a Tourist Area Cycle of Evolution: Implications for Management of Resources.” Canadian Geographer, 24(1): 5-12.

Collett, P. (1979). “The Repertory Grid in Psychological Research.” In Emerging Strategies in Social Psychological Research, edited by G. P. Ginsburg, New York: Wiley, pp. 225-252. 
Coshall, J. T. (2000). "Measurement of Tourists' Images: The Repertory Grid Approach.” Journal of Travel Research, 39(1): 85-89.

Davis, D., J. Allen, and R. M. Cosenza (1988). “Segmenting Local Residents by their Attitudes, Interests, and Opinions Toward Tourism." Journal of Travel Research, 27(2): 2-8.

Diamantis, D., and A. Ladkin (1999). ““'Green Strategies” in the Tourism and Hospitality Industries." In The International Marketing of Travel and Tourism: A Strategic Approach, edited by F. Vellas and L. Becherel. Basingstoke, UK: MacMillan, pp. $121-141$.

Doxey, G. V. (1975). A causation theory of visitor-resident irritants: Methodology and research inferences. In Proceedings of the $6^{\text {th }}$ Annual Conference of the Travel Research Association. San Diego, CA: Travel Research Association, pp. 195-198.

Easterby-Smith, M. (1981). "The Design, Analysis and Interpretation of Repertory Grids." In Recent Advances in Personal Construct Technology, edited by M. L. G. Shaw. London: Academic Press, pp. 9-30.

Embacher, J., and F. Buttle (1989). “A Repertory Grid Analysis of Austria's Image as a Summer Vacation Destination.” Journal of Travel Research, 27(3): 3-7.

Faulkner, B. (1998, December). Revisioning the Gold Coast: Gold Coast Tourism Market Analysis (Project 1.1). Gold Coast, Australia: Centre for Tourism and Hotel Management Research, Griffith University - Gold Coast Campus.

Faulkner, B., and C. Tideswell (1997). “A Framework for Monitoring Community Impacts of Tourism." Journal of Sustainable Tourism, 5(1): 3-28. 
Fenton, D. M., and G. J. Syme (1989). "Perception and Evaluation of the Coastal Zone: Implications for Coastal Zone Planning.” Coastal Management, 17: 295-308.

Fransella, F., and D. Bannister (1977). A Manual for Repertory Grid Technique. London: Academic Press Inc. (London) Ltd.

Fredline, E. (1997, June). Resident Perceptions of the Gold Coast Indy: An Exploratory Study (Social Research Studies No.3). Gold Coast, Queensland: Research Unit, Gold Coast City Council.

Fredline, E., and B. Faulkner (2000). "Host Community Reactions: A Cluster Analysis.” Annals of Tourism Research, 27(3): 764-785.

GCCC (Gold Coast City Council). (2004). Snapshot of the Gold Coast. Retrieved November 30, 2004, from http://www.goldcoast.qld.gov.au/attachment/Tourism/Profile_Part2.pdf

Gunn, C. A. (1979). Tourism Planning. New York: Crane, Russak \& Company, Inc.

Gyte, D. M. (1988). Repertory Grid Analysis of Images of Destinations: British Tourists in Mallorca. Trent working papers in geography series. Clifton, Nottingham, UK: Trent Polytechnic.

Haralambopoulos, N., and A. Pizam (1996). "Perceived Impacts of Tourism: The Case of Samos." Annals of Tourism Research, 23(3): 503-526.

Harrison, J., and P. Sarre (1971). "Personal Construct Theory in the Measurement of Environmental Images.” Environment and Behavior, 7(1), 3-58.

Harvey, M. J., J. Hunt, and C. C. Harris (1995). “Gender and Community Tourism Dependence Level.” Annals of Tourism Research, 22(2): 349-366. 
Haukeland, J. V. (1984). "Sociocultural Impacts of Tourism in Scandinavia: Studies of Three Host Communities." Tourism Management, 5(3), 207-214.

Hernandez, S. A., J. Cohen, and Garcia, H. L. (1996). "Residents' Attitudes Towards and Instant Resort Enclave.” Annals of Tourism Research, 23(4): 755-779.

Hudson, R. (1974). "Images of the Retailing Environmental: An example of the Use of the Repertory Grid Methodology.” Environment and Behaviour, 6(4): 470-494.

Husbands, W. (1989). "Social Status and Perception of Tourism in Zambia." Annals of Tourism Research, 16(2): 237-253.

Ibery, B. W., and R. Hornby (1983). "Repertory Grids and Agricultural Decision-making: A Mid-Warwickshire Case Study.” Geografiska Annaler, 65B: 77-84.

Jaffari, J. (2001). “The Scientification of Tourism.” In Hosts and Guests Revisited: Tourism Issues of the $21^{\text {st }}$ Century, edited by V. L. Smith and M. Brent. New York: Cognizant, pp. 28-41.

Jurowski, C., and D. Gursoy (2004). “Distance Effects on Residents’ Attitudes Toward Tourism.” Annals of Tourism Research, 32(2): 296-312.

King, B., A. Pizam, A., and A. Milman (1993). "Social Impacts of Tourism: Host Perceptions." Annals of Tourism Research, 20(4): 650-655.

Kelly, G. A. (1955). The Psychology of Personal Constructs. New York: Norton. Lankford, S. V., J. S.Y. Chen, and W. Chen (1994). “Tourism's Impacts in the Penghu National Scenic Area, Taiwan”. Tourism Management, 15(3): 222-227.

Lankford, S. V., A. Williams, and J. Knowles-Lankford (1994). “Developing a Tourism Impact Attitude Scale.” Annals of Tourism Research, 21(1): 121-139. 
Lew, A. (1987). “A Framework of Tourist Attraction Research.” Annals of Tourism Research, 14(4): 553-575.

Madrigal, R. (1995). "Resident's Perceptions and the Role of Government.” Annals of Tourism Research, 20(2), 336-353.

Mansfeld, Y., and O. Ginosar (1994). "Evaluation of the Repertory Grid Method in Studies of Locals' Attitudes Toward Tourism Development Process." Environment and Planning A, 26(6): 957-972.

Martin, S. R. (1995). “Montanans' Attitudes and Behavioral Intentions toward Tourism: Implications for Sustainability." In Linking Tourism, the Environment, and Sustainability (USDA Technical Report INT-GTR-323) edited by S. F. Mc Cool, and A. E. Watson. Ogeden, UT: US Department of Agriculture, Forest Service, Intermountain Research Station, pp. 69-76.

Martin, B. S., F. McGuire, and L. Allen (1998). “Retirees’ Attitudes Toward Tourism: Implications for Sustainable Development.” Tourism Analysis, 3(1): 43-51.

McClung, G. W. (1991). “Theme Park Selection: Factors Influencing Attendance.” Tourism Management, 12(2): 133-140.

McIntosh, R. W., C. R. Goeldner, and J. R. Ritchie (1995). Tourism: Principles, Practices, Philosophies $\left(7^{\text {th }}\right.$ ed.). New York: John Wiley \& Sons, Inc.

McMinn, S. and E. Cater (1998). "Tourist Typology: Observations from Belize.” Annals of Tourism Research, 25(3): 675-699.

Milman, A. and A. Pizam (1988). "Social Impacts of Tourism on Central Florida." Annals of Tourism Research, 15(2), pp.191-204. 
Mill, R. and A. Morrison. (1985). The Tourism System. Englewood Cliffs, NJ: Prentice Hall.

Mullin, P. (1992). “Cities for Pleasure: The Emergence of Tourism Urbanization in Australia." Built Environment, 18(3): 187-198.

Opacic, S. and R. B. Potter (1986). “Grocery Store Cognitions of Disadvantaged Consumer Groups: A Reading Case Study.” Tijdschrift voor Economishe en Social Geograpfie, 77(4): 288-298.

Pearce, P. L. (1982). "Perceived Changes in Holiday Destinations.” Annals of Tourism Research, 9(2): 145-164.

Pearce, P. L. (1991). “Analysing Tourist Attractions”. Journal of Tourism Studies, 2(1), 4655.

Perdue, R. R., P. T. Long, and Y. S. Kang (1995). "Resident Support for Gambling as a Tourist Development Strategy.” Journal of Travel Research, 34(2): 3-11.

Pigram, A. (1983). Outdoor Recreation and Resource Management. New York: Croom Helm.

Pigram, J. (1987). Tourism in Coffs Harbour: Attitudes, Perceptions and Implications. Armidale: North Coast Regional Office, Department of Continuing Education, University of New England.

Pizam, A. (1978). “Tourism's Impacts: The Social Costs to the Destination Community as Perceived by its Residents." Journal of Travel Research, 16(4), 8-12.

Pizam, A. and J. Pokela (1985). “The Perceived Impacts of Casino Gambling on a Community." Annals of Tourism Research, 12(2), 147-165. 
Poon, A. (1993). Tourism, Technology and Competitive Strategies. Wallingford, UK: CAB International.

Potter, R. (1986). "Spatial Inequalities in Barbados, West Indies.” Transactions of the Institute of British Geographers, New Series, 11: 183-198.

Potter, R., and J. Coshall (1988). "Sociopsychological Methods for Tourism Research." Annals of Tourism Research, 15(1): 63-75.

Preston, V., and S. M. Taylor (1981). "Personal Construct Theory and Residential Choice." Annals of the Association of American Geographers, 71(3): 437-451.

Riley, S., and J. Palmer (1976). Of Attitudes and Latitudes: A Repertory Grid Study of Perceptions of Seaside Resorts. In The Measurement of Intrapersonal Space by Grid Technique: Explorations of Intrapersonal Space, Vol.1, edited by P. Slater. London: John Wiley \& Sons Ltd, pp. 153-165.

Ross, G. F. (1991). “Community impacts of tourism among older and long-term residents.” Australian Journal on Aging, 10(4): 17-24.

Ryan, C. and D. Montgomery (1994). "The Attiudes of Bakewell Residents to Tourism and Issues in Community Responsive Tourism.” Tourism Management, 15(5), 358-369.

Schroeder, T. (1992). “Host Community Perceptions of Tourism’s Impacts: A Cluster Analysis." Visions of Leisure and Business, 10(4), 43-48.

Sheldon, P. J. and Var, T. (1984). Resident Attitudes to Tourism in North Wales." Tourism Management, 5(1): 40-47.

Smith, V. L. (Ed.). (1977). Hosts and Guests: The Anthropology of Tourism (1 ${ }^{\text {st }}$ ed.). Philadelphia, P.A.: University of Philadelphia Press. 
Smith, G. C. (1989). "Elderly Consumer Cognitions of Urban Shopping Centres. The Canadian Geographer, 33(4): 353-359.

Smith, S., and C. Leach (1972). "A Hierarchical Measure of Cognitive Complexity." British Journal of Psychology, 63: 561-568.

Son, N. T., J. J. Pigram, and P.A. Rugendyke (1999). “Tourism development and national parks in the developing world: Cat Ba Island National Park, Vietnam.” In Contemporary Issues in Tourism Development edited by D. G. Pearce and R. W. Butler. London: Routledge, pp. 211-231.

Sparrow, J., \& G. Wood (1994). "You're Stopping me from Giving Quality Service.” International Journal of Contemporary Hospitality Management, 6(1/2): 61-67.

Stewart, V., A. Stewart A., and N. Fonda (1981). Business Applications of Repertory Grid. London: McGraw-Hill Book Company (UK) Limited.

Stolz, G. (1999, 7-8 August). "Surfers Losing Heart: It's Like Watching 'Nero Fiddle while Rome Burns"”. The Gold Coast Weekend Bulletin, p.6

Stringer, P. (1974). "Individual Differences in Repertory Grid Measures for a Cross-section of the Female Population.” In Psychology and the Built Environment, edited by G. Canter and T. Lee. Kent, England: The Architectural Press Ltd., pp.96-104.

Swarbrooke, J. (1995). The Development and Management of Visitor Attractions (2 ${ }^{\text {nd }}$ ed.). UK: Butterworth-Heinemann.

Thach, P., and C. N. Axinn (1994). "Patron Assessments of Amusement Park Attributes." Journal of Travel Research, 32(3), 51-60. 
Timmermans, H., R. Van der Hijden, and H. Westerveld (1982). "Cognition of Urban Retailing Structures: A Dutch Case Study.” Tijdschrift voor Economishe en Social Geograpfie, 7(3): 2-12.

Townsend, J. G. (1976). "Farm Families: The Application of Personal Constructs in the Tropical Rainforest.” Area, 8: 219-222.

Tomljenovic, R., and B. Faulkner (2000). “Tourism and Older Residents in a Sunbelt Resort.” Annals of Tourism Research, 27(1): 93-114.

Um, S., and J. L.Crompton (1987). Measuring Residents' Attachment Levels in a Host Community. Journal of Travel Research, 26(1), 27-29.

Walmsley, D. J., and J. M. Jenkins (1993). “Appraisive Images of Tourist Areas: Application of Personal Constructs.” Australian Geographer, 24(2): 1-13.

Weaver, D. B., and L. J. Lawton (2001). "Resident Perceptions of Tourism in the UrbanRural Fringe." Annals of Tourism Research, 28(2): 439-458.

Weaver, D. B., and L. J. Lawton (2002). Tourism Management (2 ${ }^{\text {nd }}$ ed.). Milton, QLD: Australia: John Wiley \& Sons.

Wight, P. (1994). "The Greening of the Hospitality Industry: Economic and Environmental Good Sense." In Tourism: State of the Art, edited by A. V. Seaton et al. Chicester, UK: Wiley, pp. 665-674.

Wong, K. F., and W. Y. Cheung (1999). "Strategic Theming in Theme Park Marketing." Journal of Vacation Marketing, 5(4): 319-332.

Young, M. (1995). "Evaluative Constructs of Domestic Tourist Places.” Australian Geographical Studies, 33(2): 272-286. 


\section{TABLE 1}

\section{CONSTRUCTS ELICITED, BY PRIMARY CATEGORY AND FREQUENCY}

\begin{tabular}{lcccc} 
Type of & \multicolumn{2}{c}{ Actual Number of Constructs Used } & \multicolumn{2}{c}{ Total Constructs Used } \\
Construct & Number & Percentage & Number & Percentage \\
Evaluative & 44 & 35.5 & 332 & 46.4 \\
Descriptive & 48 & 38.7 & 239 & 33.5 \\
Relational & 32 & 25.8 & 144 & 20.1 \\
Total & 124 & 100.0 & 715 & 100.0
\end{tabular}


TABLE 2

\section{CONSENSUS GRID OF ATTRACTION EVALUATION MEANS}

Attractions

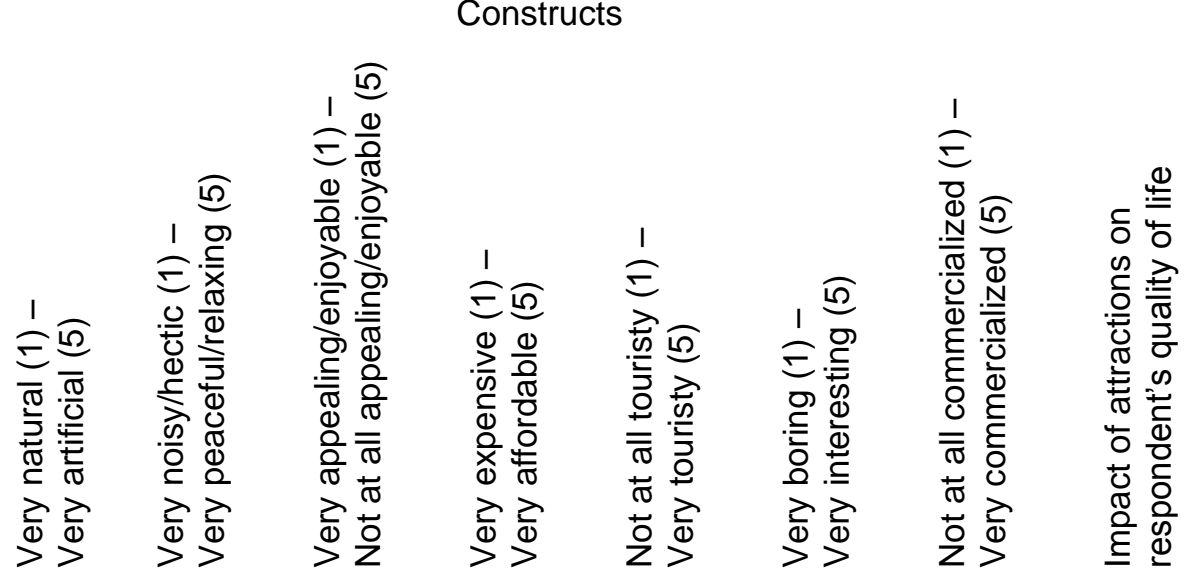

$\begin{array}{lllllllll}\text { Beach } & 1.45 & 3.90 & \underline{1.64} & 4.55 & 3.23 & 4.09 & 2.52 & 4.16 \\ \text { Springbrook NP } & 1.28 & 4.55 & 1.71 & 4.35 & \underline{2.42} & 4.19 & \underline{1.93} & 3.89 \\ \text { Tamborine Mtn } & 1.57 & 4.30 & 1.72 & 3.66 & 3.22 & 4.05 & 2.80 & 3.85 \\ \text { Lamington NP } & \underline{1.23} & 4.63 & 1.77 & 4.31 & 2.45 & 4.11 & 1.95 & 3.77 \\ \text { O'Reilly's } & 1.67 & 4.18 & 1.87 & 3.16 & 3.27 & 4.05 & 2.94 & 3.56 \\ \text { Sea World } & 3.42 & 2.27 & 1.91 & 1.74 & 4.60 & 4.21 & 4.46 & 3.50 \\ \text { Binna Burra } & 1.58 & 4.28 & 1.92 & 2.98 & 2.92 & 3.93 & 2.49 & 3.36 \\ \text { Currumbin } & 2.21 & 3.41 & 2.05 & 2.95 & 3.91 & 3.99 & 3.44 & 3.35 \\ \text { Movie World } & 4.48 & 1.67 & 2.41 & \underline{1.60} & 4.77 & 3.74 & 4.70 & 3.15 \\ \text { Dreamworld } & 3.83 & 2.00 & 2.17 & 1.75 & 4.61 & 3.86 & 4.50 & 3.14 \\ \text { Wet 'n' Wild } & 4.14 & 1.86 & 2.55 & 2.32 & 4.40 & 3.40 & 4.32 & 3.09 \\ \text { Surfers Paradise } & 4.53 & \underline{1.54} & 3.41 & 2.27 & 4.80 & \underline{2.89} & 4.80 & 2.93\end{array}$

Note: Bolded number $=$ highest mean value in column, Underline number $=$ lowest value in column 
TABLE 3

\section{SELECTED CONSENSUS GRID CELL MEANS BY CLUSTER}

\begin{tabular}{|c|c|c|c|c|c|}
\hline \multirow[t]{2}{*}{ Attraction } & \multirow[t]{2}{*}{ Construct } & \multicolumn{4}{|c|}{ Cluster } \\
\hline & & 1 & 2 & 3 & 4 \\
\hline \multirow[t]{7}{*}{ Surfers Paradise } & Natural - Artificial & 4.58 & 4.74 & 3.78 & 3.74 \\
\hline & Noisy - Peaceful & 1.45 & 1.39 & 2.41 & 2.00 \\
\hline & Appealing - Not appealing & 3.43 & 3.64 & 2.97 & 2.47 \\
\hline & Expensive - Affordable & 2.35 & 2.08 & 2.47 & 2.68 \\
\hline & Not touristy - Touristy & 4.84 & 4.91 & 4.41 & 4.38 \\
\hline & Boring - Interesting & 2.84 & 2.70 & 3.29 & 3.83 \\
\hline & Not commercialized - Commercialized & 4.80 & 4.91 & 4.48 & 4.55 \\
\hline \multirow[t]{7}{*}{ Movie World } & Natural - Artificial & 4.50 & 4.76 & 3.66 & 3.60 \\
\hline & Noisy - Peaceful & 1.68 & 1.47 & 2.17 & 2.15 \\
\hline & Appealing - Not appealing & 2.32 & 2.64 & 2.40 & 1.64 \\
\hline & Expensive - Affordable & 1.64 & 1.41 & 1.98 & 2.00 \\
\hline & Not touristy - Touristy & 4.82 & 4.85 & 4.24 & 4.53 \\
\hline & Boring - Interesting & 3.45 & 4.62 & 3.85 & 3.78 \\
\hline & Not commercialized - Commercialized & 4.74 & 4.85 & 4.03 & 4.32 \\
\hline \multirow[t]{7}{*}{ Currumbin } & Natural - Artificial & 2.05 & 2.59 & 1.98 & 1.34 \\
\hline & Noisy - Peaceful & 3.61 & 3.09 & 3.21 & 4.13 \\
\hline & Appealing - Not appealing & 1.83 & 2.39 & 2.24 & 1.23 \\
\hline & Expensive - Affordable & 3.10 & 2.66 & 2.81 & 3.83 \\
\hline & Not touristy - Touristy & 3.90 & 4.14 & 3.57 & 3.00 \\
\hline & Boring - Interesting & 4.24 & 3.60 & 3.93 & 4.74 \\
\hline & Not commercialized - Commercialized & 3.37 & 3.73 & 3.07 & 2.53 \\
\hline O'Reilly's & Natural - Artificial & 1.40 & 1.93 & 2.41 & 1.15 \\
\hline
\end{tabular}




\begin{tabular}{|c|c|c|c|c|c|}
\hline & Noisy - Peaceful & 4.50 & 3.89 & 3.28 & 4.79 \\
\hline & Appealing - Not appealing & 1.48 & 2.29 & 2.57 & 1.13 \\
\hline & Expensive - Affordable & 3.24 & 2.92 & 3.00 & 4.23 \\
\hline & Not touristy - Touristy & 3.28 & 3.51 & 3.09 & .98 \\
\hline & Boring - Interesting & 4.43 & 3.61 & 3.45 & 4.79 \\
\hline & Not commercialized - Commercialized & 2.79 & 3.26 & 3.07 & 1.91 \\
\hline Lamington NP & Natural - Artificial & 1.08 & 1.25 & 2.14 & .04 \\
\hline & Noisy - Peaceful & 4.85 & 4.58 & 3.53 & 4.81 \\
\hline & Appealing - Not appealing & 1.41 & 2.10 & 2.60 & .21 \\
\hline & Expensive - Affordable & 4.47 & 4.24 & 3.38 & 4.70 \\
\hline & Not touristy - Touristy & 2.40 & 2.59 & 2.69 & 1.66 \\
\hline & Boring - Interesting & 4.48 & 3.74 & 3.34 & 4.74 \\
\hline & Not commercialized - Commercialized & 1.79 & 2.11 & 2.67 & 1.28 \\
\hline
\end{tabular}


TABLE 4

IMPACT OF ATTRACTIONS ON RESIDENTS' QUALITY OF LIFE BY CLUSTER



Footnote: *Bolded number $=$ highest mean in row, Underline number $=$ lowest mean in row 
TABLE 5

COMPARISION OF CLUSTERS BY SEX, AGE AND LENGTH OF RESIDENCE

Variable

Cluster

test

sig.

1

2

3

4

Sex

\begin{tabular}{|c|c|c|c|c|c|c|}
\hline Female (\%) & 53.2 & 49.1 & 56.9 & 74.5 & $X^{2}=10.768^{*}$ & .013 \\
\hline Male (\%) & 46.8 & 50.9 & 43.1 & 25.5 & & \\
\hline \multicolumn{7}{|l|}{ Age } \\
\hline $18-29(\%)$ & 11.5 & 18.5 & 8.9 & 4.3 & & \\
\hline $30-39(\%)$ & 15.8 & 19.2 & 10.7 & 14.9 & $X^{2}=19.537^{*}$ & .021 \\
\hline $\begin{array}{l}40-59(\%) \\
60+(\%)\end{array}$ & $\begin{array}{l}40.9 \\
31.8\end{array}$ & $\begin{array}{l}39.2 \\
23.1\end{array}$ & $\begin{array}{l}46.4 \\
33.9\end{array}$ & $\begin{array}{l}42.6 \\
38.3\end{array}$ & & \\
\hline Mean (years) & $50.8^{3,4}$ & $46.6^{3}$ & $52.6^{1,2,4}$ & $53.8^{1,3}$ & $F=5.394$ & .001 \\
\hline \multicolumn{7}{|l|}{ Length of } \\
\hline \multicolumn{7}{|l|}{ Residence } \\
\hline 10 years or less $(\%)$ & 32.3 & 40.6 & 55.2 & 43.5 & & \\
\hline$>10$ to 20 years (\%) & 33.2 & 37.1 & 32.8 & 30.4 & $X^{2}=22.759^{*}$ & .001 \\
\hline > 20 years $(\%)$ & 34.4 & 22.4 & 12.1 & 26.1 & & \\
\hline Mean (years) & $18.0^{4}$ & $14.7^{3,4}$ & $11.58^{2,4}$ & $14.88^{1,2,3}$ & $F=7.796$ & .000 \\
\hline
\end{tabular}

Footnote:* Chi-square calculations based on original raw data rather than percentages. 


\section{TABLE 6}

\section{SYNOPSIS OF CLUSTERS}

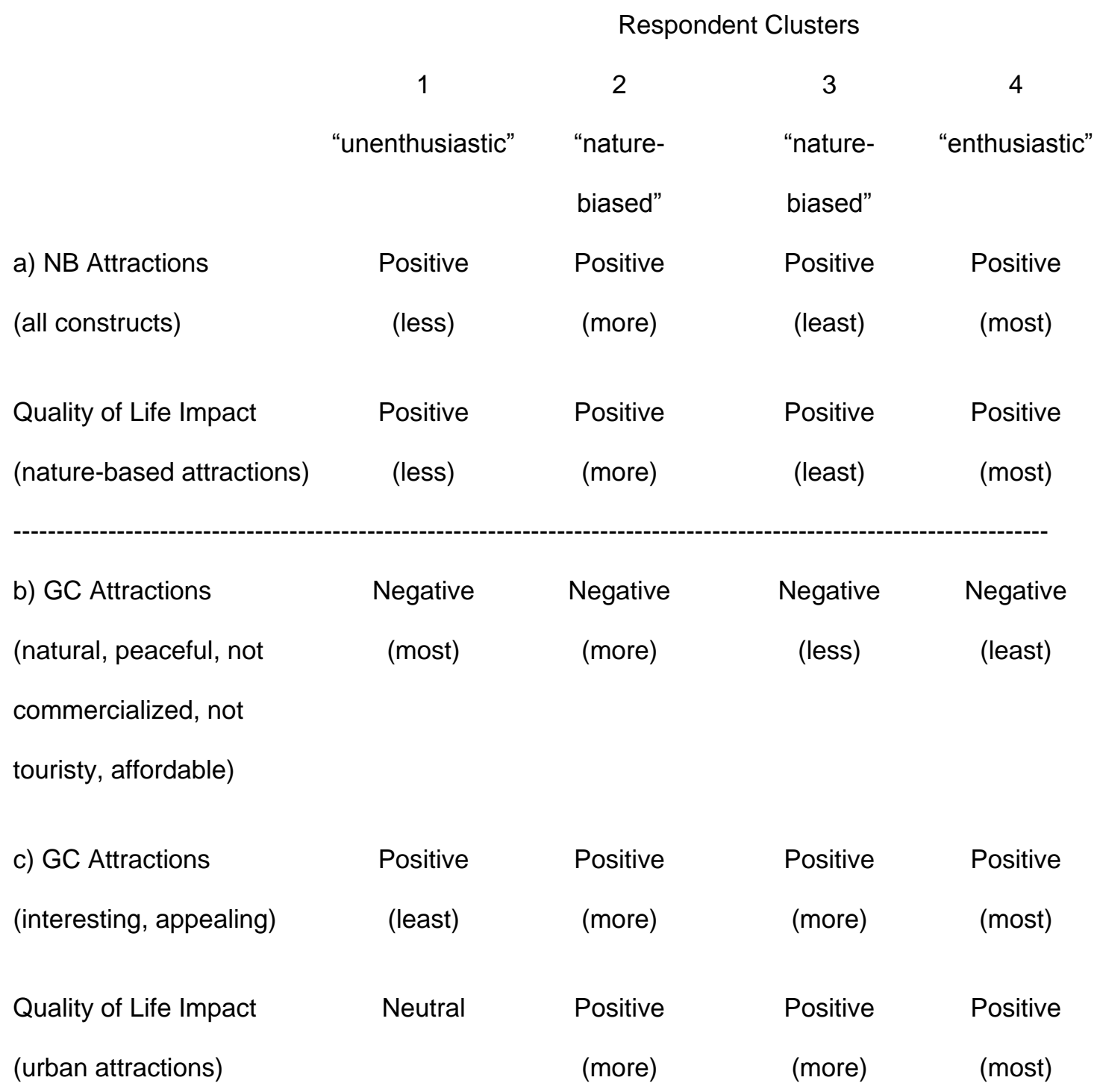

Visitation

Fewer have

visited the

hinterland

Frequency of Visits

Fewer visits

to hinterland 
Sex

Age

Length of Residence

Income
Higher

proportion

of females

Oldest
Youngest

Longest

Highest

proportion of

low-income 
FIGURE 1

\section{SELECTED CONSTRUCTS FOR STAGE THREE SURVEY}

\begin{tabular}{rll}
\hline Natural & - & Artificial \\
Peaceful/relaxing & - & Noisy/hectic \\
Appealing/enjoying & - & Not appealing/Enjoyable \\
Affordable & - & Expensive \\
Not touristy & - & Touristy \\
Interesting & - & Boring \\
Not commercialized & - & Commercialized \\
\hline
\end{tabular}


FIGURE 2

SIMPLIFIED MODEL OF ATTRACTION CONSENSUS GRID

Expensive

Artificial

Noisy/hectic

Touristy

Commercialized

Affordable

Natural

Peaceful/relaxing

Not touristy

Not commercialized

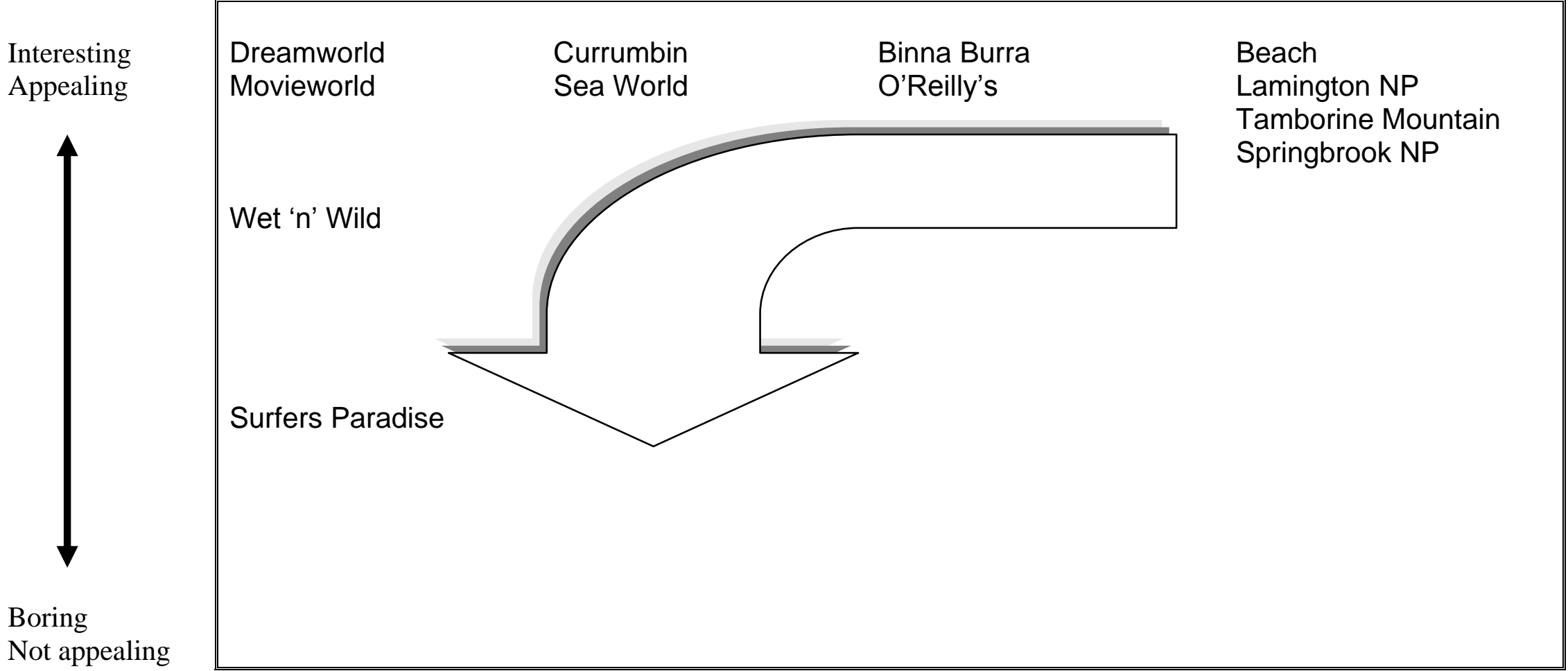


